\title{
Optimalisasi Pemanfaatan Tanaman Penjernih Udara di Lingkungan SMA/SMK/Sederajat Kecamatan Rengel dan Plumpang Kabupaten Tuban Jawa Timur
}

\author{
Kuntum Febriyantiningrum ${ }^{1 *}$, Dwi Oktafitria ${ }^{1}$, Nia Nurfitria ${ }^{1}$ \\ ${ }^{1}$ Universitas PGRI Ronggolawe, Jl. Manunggal No.61, Tuban \\ 1*kuntum060290@gmail.com
}

\begin{abstract}
Abstrak
Tujuan program pengabdian masyarakat ini adalah untuk membantu dan meningkatkan upaya konservasi lingkungan yang lebih efektif, efisien, dan terarah bagi sekolah di kawasan karst dalam mewujudkan lingkungan yang sehat bebas polusi udara. Permasalahan yang dihadapi oleh mitra adalah kurangnya partisipasi sekolah di kawasan karst untuk menangani volume debu yang meningkat pada musim kemarau yang dapat mengganggu kegiatan belajar mengajar. Partisipasi sekolah yang rendah disebabkan kurangnya pengetahuan siswa dan guru akan tanaman penjernih udara yang dapat ditanam di lingkungan sekolah. Solusi yang ditawarkan untuk mitra sekolah sebagai langkah awal yaitu dengan diadakannya workshop pengenalan kawasan karst dan jenis tanaman yang bermanfaat sebagai penjernih udara. Pelakasanaan workshop yang telah dilakukan dapat meningkatkan pemahaman siswa-siswi dan guru mengenai kondisi lingkungan sekolah, jenis-jenis tanaman penjernih udara, dan pemanfaatan bahan bekas untuk media tanam. Hasil monitoring menunjukkan bahwa sekolah mitra yaitu SMAN 1 Rengel dan SMAN 1 Plumpang sudah menerapkan hasil workshop, yaitu dengan penanaman berbagai macam tanaman penjernih udara dengan memanfaatkan bahan bekas sebagai media tanam sehingga dapat tercapai lingkungan yang asri dan konservasi lingkungan di sekolah kawasan karst berjalan dengan baik.
\end{abstract}

Kata Kunci: sekolah kawasan karst; tanaman penjernih udara;konservasi lingkungan

\section{Abstract}

'The purpose of this community service program is to help and enhance environmental conservation efforts that are more effective, efficient, and targeted for schools in the karst region in creating a healthy environment free of air pollution. The problem faced by partners is the lack of school participation in the karst area to deal with the increasing dust volume in the dry season which can disrupt teaching and learning activities. Low school participation is due to a lack of student and teacher knowledge about air-purifying plants that can be planted in the school environment. The solution offered to school partners as a first step is to hold a workshop to introduce karst areas and plant species that are useful as air purifiers. The implementation of the workshops that have been carried out can increase the understanding of students and teachers about the condition of the school environment, types of air purification plants, and the use of used materials for growing media. The monitoring results show that the partner schools namely SMAN 1 Plumpang and SMAN 1 Rengel have implemented the results of the workshop, namely by planting various air purification plants by utilizing used materials as planting media so as to achieve a beautiful environment and environmental conservation in the karst school area running well.

Keywords: karst school area; air purification plants; environmental conservation

\section{Pendahuluan}

Karst merupakan suatu wilayah dengan kondisi hidrologi khusus sebagai akibat dari komposisi batuan yang mudah larut tetapi memiliki porositas yang baik. Pembentukan bentuk lahan karst dipengaruhi oleh curah hujan yang cukup, temperatur, penutup lahan, dan formasi batuan itu sendiri. Curah hujan merupakan media pelarut utama dalam proses pembentukan karst. Karena dalam batuan karst terdapat mineral $\mathrm{CaCO}_{3}$ dan jika bersenyawa dengan air hujan yang bersifat asam, akan terlarut dan kemudian meninggalkan bekas-bekas lubang. Hal tersebut akan berdampak pada

Volume 1, Nomor 2, 2019

ISSN 2657-1439 (Print), ISSN 2684-7043 (Online) lapisan tanah diatasnya yang akan bersifat kering, gersang dan cenderung tidak subur. Karena jika terjadi hujan maka air akan langsung meresap kedalam tanah yang kemudian akan masuk kedalam sungai bawah tanah.

Menurut klasifikasi Cvijic tahun 1914, daerah Karst di Tuban termasuk dalam Merokarst dimana merupakan karst dengan perkembangan tidak sempurna dengan hanya mempunyai sebagian ciri bentuk lahan karst. Merokarst berkembang pada batu gamping yang relatif tipis dan tidak murni. Namun hal ini merupakan potensi sumber daya alam tersendiri 
bagi kabupaten Tuban. Hal ini karena sifat batu gamping yang tidak murni dan sangat cocok bagi industri pengolahan semen.

Berbagai penggunaan lahan di daerah Karst bisa dikatakan terbatas hanya pada lahan penambangan batu kapur, tegalan dan permukiman, maka tidak heran terdapat beberapa sekolah yang dibangun pada lahan karst. Sekolah yang berdiri di kawasan karst kabupaten Tuban salah satunya adalah SMAN 1 Rengel dan SMAN 1 Plumpang. Hal ini lah yang mendorong tim pengusul untuk mencoba menjalin kemitraan dengan pihak SMAN 1 Rengel dan SMAN 1 Plumpang di Kabupaten Tuban dengan cara memberikan solusi atas permasalahan prioritas yang dihadapi oleh pihak sekolah.

Mitra pertama adalah SMAN 1 Rengel yang berlokasi di jalan raya Banjaragung, desa Banjaragung, kecamatan Rengel, kabupaten Tuban, Jawa Timur. SMA Negeri Rengel ini berjarak $\pm 26 \mathrm{~km}$ dari lokasi kampus Universitas PGRI Ronggolawe. SMAN 1 Rengel merupakan salah satu sekolah yang telah berpartisipasi dalam program Adiwiyata oleh Kementerian Lingkungan Hidup dalam lingkup kabupaten Tuban.

SMAN 1 Rengel merupakan sekolah dengan luas wilayah tanah terluas di Kecamatan Rengel yang di dalamnya terdapat hutan lindung yang memang tidak boleh dimanfaatkan selain sebagai peruntukannya. Disamping itu lokasi sekolah yang berdekatan dengan lokasi penambangan serta pembakaran batu kapur milik industri kecil masyarakat, memiliki dampak yang besar terhadap keberadaan sekolah. Perkembangan sektor industri yang diharapkan untuk meningkatkan taraf hidup dan kesejahteraan manusia juga dapat memberikan kerugian bagi manusia dan lingkungan jika tidak dikelola dan dijaga dengan baik. Pencemaran udara telah menjadi masalah kesehatan lingkungan utama di dunia, khususnya di negara berkembang, baik pencemaran udara dalam ruangan maupun udara ambien di perkotaan dan pedesaan. Berbagai faktor berpengaruh dalam timbulnya penyakit atau gangguan pada saluran napas akibat debu khususnya debu tanah kapur dan debu dari pembakaran batu kapur. Faktor itu antara lain adalah faktor debu yang meliputi ukuran partikel, bentuk, konsentrasi, daya larut dan sifat kimiawi, serta lama paparan (Septyaningrum, 2014).

Di Indonesia, penyakit atau gangguan paru akibat debu diperkirakan cukup banyak. Hal ini pula yang akan berdampak terhadap siswa-siswa yang memiliki sekolah di dekat kawasan karst. SMAN 1 Rengel berupaya dalam melakukan penghijauan di lingkungan sekolah salah satunya untuk meningkatkan kesehatan warga sekolah. Dengan luas tanah yang tergolong lebar, SMAN 1 Rengel masih memiliki beberapa lokasi tanah yang memang belum termanfaatkan sebagai taman penghijauan. Hal ini masih merupakan rencana jangka panjang pihak sekolah dalam memanfaatkan lahan tersebut.

Mitra kedua adalah SMAN 1 Plumpang yang berlokasi di Jalan Raya Sumberagung, Desa Sumberagung, Kecamatan Plumpang, Kabupaten Tuban, Jawa Timur. Lokasi mitra berjarak $\pm 15 \mathrm{~km}$ dari kampus Universitas PGRI Ronggolawe. SMAN 1 Plumpang merupakan salah satu sekolah yang tergolong baru dalam berpartisipasi pada program Adiwiyata oleh Kementerian Lingkungan Hidup dalam lingkup Kabupaten Tuban. Lokasi sekolah yang sangat strategis di tepi jalan raya dan berada di wilayah karst membuat lingkungan sekolah beresiko terdampak polusi udara yang tinggi. Polusi udara diartikan sebagai adanya bahan-bahan atau zat-zat asing di dalam udara yang menyebabkan perubahan susunan (komposisi) udara dari keadaan normalnya (Al Idrus, 2013).

Beberapa macam komponen pencemar udara dan yang paling banyak dalam pencemaran udara adalah komponen- komponen berikut ini 1) Karbon Monoksida (CO); 2) Nitrogen Oksida (NOx); 3) Belerang Oksida (SOx); 4) Hidrokarbon (HC); 5) Partikel (Wardhana, 2004). Pencemaran udara adalah bertambahnya bahan atau substrat fisik atau kimia ke dalam lingkungan udara normal yang mencapai sejumlah tertentu, sehingga dapat dideteksi oleh manusia (atau yang dapat dihitung dan diukur) serta dapat memberikan efek pada manusia, binatang, vegetasi, dan material (Fardiaz, 1992). Sehingga pihak SMAN 1 Plumpang sangat fokus terhadap kesehatan warga sekolah khususnya pada pencemaran polusi yang diakibatkan oleh partikel debu tanah kapur. Jumlah partikel debu tanah kapur akan meningkat sangat tinggi pada musim kemarau dimana kecepatan angin mampu mendorong partikel tersebut terangkat ke udara yang dapat terhirup oleh manusia.

SMAN 1 Plumpang berupaya pula dengan membuat lingkungan sekolah menjadi lebih hijau dengan pembuatan taman-taman dan penanaman tanaman peneduh. Hal ini secara langsung dapat mereduksi jumlah partikel debu tanah kapur yang terhirup oleh warga sekolah. Berbagai upaya meningkatkan kesehatan warga sekolah dilakukan oleh pihak sekolah yang mengantarkan SMAN 1 Plumpang meraih Juara I dalam Lomba Sekolah Sehat Tingkat Kabupaten dan Juara Harapan III Tingkat Propinsi Jawa Timur.

SMAN 1 Plumpang memiliki tim relawan konservasi lingkungan dari siswa-siswi sekolah sendiri yang berupaya besar membangun lingkungan sekolah yang hijau, asri dan sehat. Langkah-langkah pembuatan taman, green house dan biopori telah dilakukan walaupun memiliki kendala yaitu kesuburan tanah yang minim dikarenakan tanah diatas SMAN 1 Plumpang adalah tanah bekas pertanian tebu. 


\section{Bahan dan Metode}

Kegiatan pengabdian ini dilakukan melalui beberapa tahapan, yaitu tahap persiapan, pelaksanaan workshop dan monitoring.

\section{a. Tahap Persiapan}

Tahap persiapan dimulai dengan melakukan observasi lapangan di SMA N 1 Rengel dan SMA N 1 Plumpang. Selanjutnya tim melakukan pendekatan dengan Kepala Sekolah pada masing-masing mitra untuk mendapatkan data, keinginan dan rencana pelaksanaan program PKM. Kemudian mempersiapkan perlengkapan dan kebutuhan yang akan digunakan serta mengurus perijinan dan administrasi serta langkah operasional.

b. Tahap Pelaksanaan

Pelaksanaan program PKM dilakukan dengan cara memberikan materi secara teori dan praktik melalui workshop yang diselenggarakan selama 1 hari. Pelaksanaan workshop ini berlangsung pada hari kamis, tanggal 15 November 2015 di SMA N 1 Plumpang. Pada acara ini, juga dilakukan diskusi untuk mengetahui kondisi pemahaman para siswa yang mengikuti acara. Materi teori dan praktek mencakup penyelesaian dari permasalahan prioritas mitra yaitu pengenalan kawasan karst, konservasi kawasan karst di lingkungan sekolah serta pengenalan jenis tanaman yang bermanfaat sebagai penjernih udara. Dalam tahap pelaksanaan workshop juga turut mengundang perwakilan SMA/SMK/MA sederajat selain pihak mitra dilingkup kecamatan Rengel dan Plumpang.

c. Tahap Monitoring

Monitoring dilakukan secara berkala yaitu dua kali selama program PKM berlangsung dengan cara survei ke tempat mitra untuk mengetahui kendala maupun permasalahan yang muncul selama waktu program PKM dan mencatat data-data yang diperlukan untuk evaluasi.

d. Tahap Evaluasi

Evaluasi dilakukan setelah monitoring untuk mengetahui seberapa jauh keberhasilan hasil program PKM yang telah dilaksanakan. Keberhasilan program ini dapat dilihat dari beberapa kategori, yaitu dengan melihat bertambahnya jumlah tanaman yang mampu menyerap polusi dan menjernihkan udara, dan kebermanfaatan limbah yang dimanfaatkan sebagai media dalam menanam tanaman penyerap polusi. Berdasarkan hal itu maka dapat diketahui faktor peluang dan kendala serta dampak positif bagi siswa dan pihak sekolah, sehingga dapat ditarik kesimpulan untuk pengembangan dan kelanjutan program PKM selanjutnya yang diharapkan akan tetap terjalin komunikasi dan diskusi antar pihak sekolah dan pihak akademisi.

\section{Hasil dan Pembahasan}

a. Workshop Pengenalan Kawasan Karst dan Tumbuhan Perjernih Udara

Tahap pertama pelaksanaan program pengabdian kepada masyarakat ini adalah one day workshop yang dilakukan pada tanggal 15 November 2018 bertempat di Laboratorium IPA, SMA Negeri 1 Plumpang yang beralamatkan di jalan raya Pakah-Plumpang, Desa Sumberagung Kecamatan Plumpang Kabupaten Tuban. Workshop ini diikuti oleh 18 peserta mitra dalam program ini yaitu perwakilan siswa dan guru pendamping dari 6 Sekolah Menengah Atas yang terletak di Kecamatan Plumpang dan Rengel. Acara ini terbagi menjadi 3 sesi.

Sesi pertama merupakan sesi pengenalan kawasan karst dan tanaman penjernih udara yang didampaikan oleh Tim Pelaksana Program Pengabdian Kepada Masyarakat FMIPA Universitas PGRI Ronggolawe Tuban. Sebelum sesi pertama dimulai dilakukan kuisioner pra workshop untuk mengetahui pengetahuan peserta tentang mengenai kondisi dan lingkungan sekolah mereka yang terletak dalam wilayah pegunungan karst. Hasil kuisioner didapatkan bahwa $82 \%$ peserta setuju jika ada dampak negatif yaitu polusi udara akibat aktivitas tambang batu kapur di pegunungan karst di lingkungan peserta. Namun, 71\% dari peserta belum mengetahui cara mengurangi dampak tersebut sehingga $100 \%$ peserta bersedia untuk berperan aktif dalam menguranginya. Oleh karena itu, dapat disimpulkan bahwa sebagian besar peserta workshop belum sepenuhnya memahami kondisi lingkungan sekolah. Hasil pra acara tahap pertama program ini telah sesuai dengan latar belakang yang telah disurvei oleh tim sehingga diharapkan tujuan pelaksanaan program ini akan tercapai sesuai yang diharapkan.

Pada sesi pertama inilah, siswa-siswi perwakilan SMA/SMK/MA sederajat dikenalkan bagaimana kondisi lingkungan sekolah mereka yang berada pada kawasan karst. Kawasan karst merupakan kawasan yang $70 \%$ wilayahnya didominasi oleh tanah dan batuan kapur. Selain itu, di kawasan karst ini juga dimanfaatkan untuk pemenuhan sumberdaya alam seperti batu gamping, kapur dan semen yang dapat menyumbangkan polusi udara pada saat proses pengerjaan dan pengolahannya. Polusi udara ini berupa partikel padat yang memiliki komposisi kalsium karbonat $\left(\mathrm{CaCO}_{3}\right)$ dalam bentuk teremulsi dan tidak di dalam udara,serta gas buang pabrik $\left(\mathrm{CO}_{\mathrm{x}}, \mathrm{SO}_{\mathrm{x}}\right.$, dll). Sesi ini kemudian dilanjutkan dengan pemberian materi mengenai jenis-jenis tanaman yang berpotensi menyerap polusi udara. Pengetahuan mitra terhadap jenis-jenis tanaman ini adalah hal dasar yang penting agar upaya penanganan polusi udara yang terjadi di sekitar lingkungan/ kawasan sekolah mitra dapat berjalan secara efisien dan tepat sasaran. 


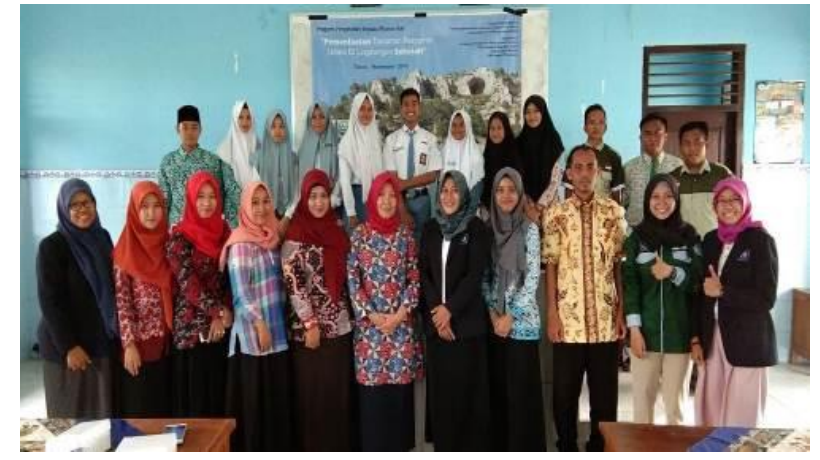

Gambar 1 Foto bersama Pemateri dan Peserta Workshop

Untuk sesi kedua, workshop diisi dengan penyampaian materi terkait pemanfaatan sampah bekas atau limbah sebagai media tanam untuk menanam tanaman di lingkungan sekolah sehingga dapat mengurangi polusi yang terjadi di lingkungan sekolah. Sealin itu, pemanfaatan sampah bekas dan limbah sebagai media tanam ini juga diharapkan dapat menunjang penanaman tanaman anti polusi udara yang pada akhir acara workshop akan diberikan kepada sekolah mitra. Materi pada sesi kedua disampaikan oleh Ibu Susana, Ketua Bank Sampah Kabupaten Tuban. Pada materi ini, para peserta workshop diedukasi dengan bagaimana cara pemilahan sampah yang bisa dimanfaatkan lagi dan tidak, serta bagaimana pengelolaannya yang tepat.

Sesi ketiga merupakan sesi tanya jawab terkait materi yang disampaikan oleh tim pelaksana pengabdian kepada masyarakat dari FMIPA Universitas PGRI Ronggolawe Tuban dan pemateri tamu dari Bank Sampah Kota Tuban. Pada sesi ketiga ini, kami melakukan diskusi kecil antara peserta, pemateri yang berasal dari Bank Sampah Kab. Tuban, dan tim pelaksana terkait. Peserta workshop terlihat sangat antusias dan aktif selama proses diskusi berlangsung (Gambar 2).

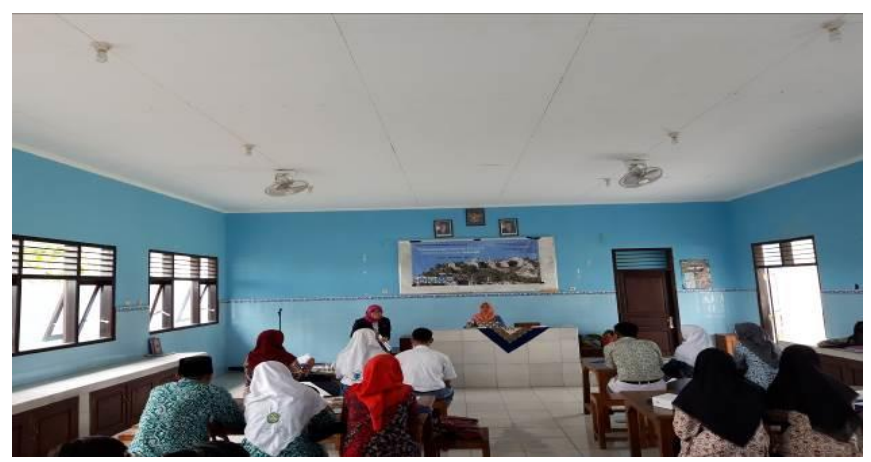

Gambar 2 Antusiasme peserta one day workshop di SMA Negeri 1 Plumpang
Acara workshop yang kami selenggarakan diakhiri dengan membagikan tanaman penjernih udara sebagai modal awal sekolah mitra untuk mengenalkan kepada siswa-siswinya terkait tanaman penjernih udara di lingkungan sekolah (Gambar 3).

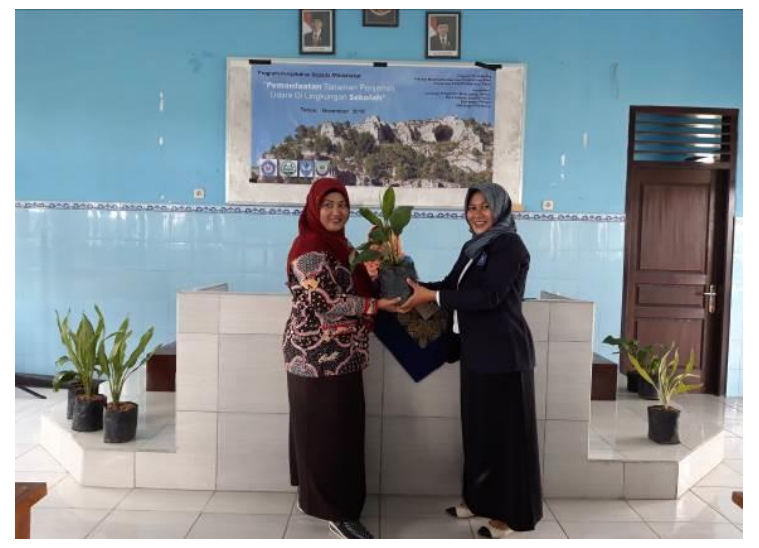

Gambar 3 Penyerahan Inisiator Tanaman Penjernih Udara Kepada Mitra

Beberapa tanaman penjernih udara yang selanjutnya digunakan sebagai inisiator tanaman penjermih udara oleh kedua sekolah mitra adalah Sansievera sp., sri rejeki, paku tanduk rusa, dll. Tanaman ini nantinya akan ditanam dengan menggunakan bahan bekas di lingkungan sekolah. Kegiatan inilah yang diharapkan oleh pelakasana untuk dijadikan sebagai sumber pembelajaran pengenalan tumbuhan anti polusi udara kepada siswa-siswi sekolah mitra sekaligus sumber penjernih udara di lingkungan sekolah mitra.

\section{b. Proses Monitoring dan Evaluasi}

Monitoring merupakan kegiatan pemantauan hasil dan tindak lanjut oleh pelaksana kepada sekolah mitra yang dilakukan 1 bulan setelah pelaksanaan workshop. Tujuan kegiatan monitoring ini adalah untuk melihat tindak lanjut sekolah mitra setelah siswa-siswinya diedukasi mengenai pengenalan tanaman penyerap polusi udara di kawasan karst serta penggunaan bahan bekas sebagai media tanam pada saat workshop. Tindak lanjut yang akan dilihat oleh tim pelaksana program Pengabdian kepada Masyarakat adalah apakah di sekolah mitra sudah menanam tanaman yang kami sarankan untuk dapat mengatasi permasalahan terkait polusi udara serta permasalahan dan kendala selama aplikasi materi yang telah diberikan pada saat workshop.

Pelaksanaan monitoring di sekolah mitra 1 (SMAN 1 Plumpang) yang dilakukan pada tanggal 15 Desember 2018, menunjukkan bahwa pihak sekolah sudah mulai menanam tanaman-tanaman penyerap polusi udara di lingkungan sekolah. Pada SMAN 1 Rengel, kegiatan monitoring juga dilakukan satu bulan setelah workshop berlangsung. SMAN 1 Rengel yang berkedudukan sebagai sekolah mitra sudah mulai 
menanam tanaman penjernih udara dan mengedukasi siswa-siswinya untuk lebih mencintai lingkungan dengan tidak membuang sampah sembarangan, mengurangi penggunaan sampah, memilah sampah, dan juga mulai menggunakan sampah sebagai media tanam untuk tanaman. Kemajuan yang kami dapatkan ketika melakukan monitoring di SMAN 1 Rengel ternyata cukup memuaskan. Kami juga melihat antusiasme siswa-siswi sekolah untuk menjaga lingkungannya dan memanfaatkan limbah botol air mineral sebagai wadah untuk menanam penjernih udara yang dapat dilihat pada Gambar 4 .

Hasil ini menunjukkan bahwa edukasi pengolahan sampah untuk media tanam saat workshop sudah berhasil dan dapat diaplikasikan oleh pihak sekolah, khususnya oleh siswa. Hasil ini menunjukkan salah satu indikator keberhasilan pelaksanaan pengabdiaan kepada masyarakat yang dilakukan oleh pelaksana.

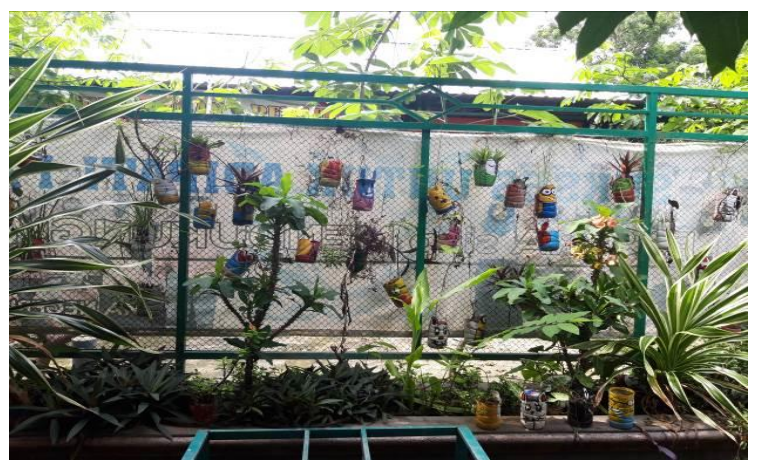

Gambar 4 Penggunaan botol plastik bekas untuk media tanam di SMAN 1 Rengel

Jika diamati lebih lanjut, SMAN 1 Rengel adalah salah satu SMA di Kabupaten Tuban yang berada pada wilayah berpotensi mengalami polusi udara karena lokasinya yang berada di kawasan karst dan berdekatan dengan lokasi penambangan pengolahan batu kapur.

Untuk mengatasi masalah ini, pihak SMAN 1 Rengel terus aktif berupaya untuk melakukan langkahlangkah preventif seperti menanam tanaman penjernih udara dalam jumlah besar. Berdasarkah hasil monitoring, tanaman penjernih udara sudah banyak dijumpai di area sekolah ini. Hal ini didukung oleh bertambahnya pengetahuan mereka setelah mengikuti workshop terkait kondisi lingkungan dan penanaman tanaman yang tepat bagi lingkungan sekolah. Jumlah tanaman dan spot taman yang dapat menyerap polusi udara juga lebih banyak jika dibandingkan dengan SMA N 1 Plumpang.

Demikian halnya dengan mitra kedua, yaitu SMAN 1 Plumpang, penanaman tanaman penjernih udara ditandai dengan adanya tanaman Sansievera sp. di beberapa sudut lahan yang masih kosong. Tanaman ini menjadi tanaman yang cukup favorit karena mudah didapat dan memiliki nilai guna yang cukup banyak.

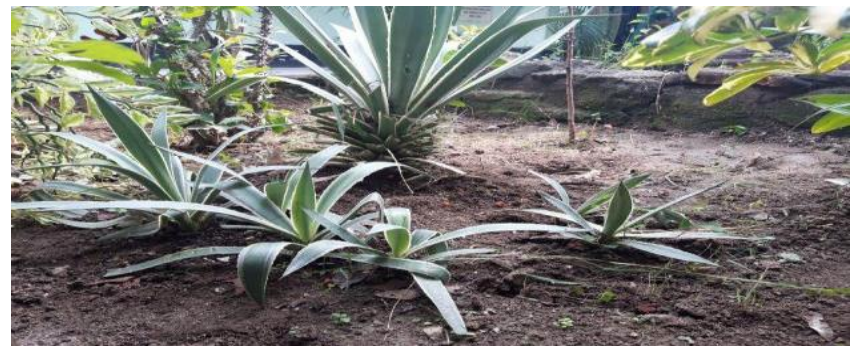

Gambar 5 Tanaman Sansievera sp. yang ditanam di halaman SMAN 1 Plumpang

Hasil positif yang ditunjukkan oleh sekolah mitra pada tahap monitoring merupakan indikator keberhasilan pelaksanaan serangkaian program Pengabdian Kepada Masyarakat ini. Namun, keberlanjutan penanaman dan perawatan tanaman polusi udara yang ada di sekolah mitra merupakan kunci kesuksesan penjernihan udara dilingkungan sekolah oleh tanaman penjernih udara.

\section{Kesimpulan dan Saran}

Berdasarkan hasil pelaksanaan dan monitoring kegiatan Pengabdian Kepada Masyarakat dengan judul" Optimalisasi Pemanfaatan Tanaman Penjernih Udara Di Lingkungan SMA/SMK Sederajat di Kecamatan Rengel dan Plumpang Kabupaten Tuban, Jawa Timur" sudah berjalan sesuai tujuan yang diharapkan. Pelakasanaan workshop meningkatkan pemahaman siswa-siswi dan guru mengenai kondisi lingkungan sekolah, jenis-jenis tanaman penjernih udara, dan pemanfaatan bahan bekas untuk media tanam. Hasil monitoring menunjukkan bahwa sekolah mitra yaitu SMA N 1 Plumpang dan SMA N 1 Rengel sudah menrapkan hasil workshop dengan dibuatnya taman tematik anti polusi udara menggunakan bahan bekas sebagai media tanam.

\section{Ucapan Terima Kasih}

Terimakasih kepada Lembaga Pengabdian Masyarakat (LPM) Universitas PGRI Ronggolawe Tuban yang telah mendanai program kemitraan. Terimakasih yang tak terhingga kepada kedua mitra, yaitu SMA N 1 Plumpang dan SMA N 1 Rengel, serta peserta workshop dari seluruh SMA/SMK/MA sederajat di Kecamatan Plumpang dan Rengel yang telah berpartisipasi selama program kemitraan ini berlangsung.

\section{Daftar Rujukan}

Al Idrus, S. W. (2013) 'Pencemaran Udara Akibat Pengolahan Batu Kapur Dusun Open Desa Mangkung Praya Barat', Jurnal Pijar MIPA, VIII(2), pp. 85-90.

Fardiaz, Srikandi. (1992). Polusi air dan udara. Jogjakarta : Kanisius. 
Septyaningrum, M. (2014) Hubungan Paparan

Debu Kapur Dengan Penurunan Fungsi

Paru Pada Tenaga Kerja PT. Putri Indah

Pertiwi, Desa Pule, Gedong, Pracimantoro,

Wonogiri.

Wardhana, W.A. (2004). Dampak Pencemaran

Lingkungan. Yogyakarta: Andi. 